\title{
REFLEXIONES CRÍTICAS Y PRÁCTICAS EN TORNO AL RÉGIMEN JURÍDICO DEL CAMBIO NACIONAL Y TRANSFRONTERIZO DEL DOMICILIO DEL MENOR DE EDAD
}

\author{
CRITICAL AND PRACTICAL REFLECTIONS ON THE LEGAL \\ REGIME OF NATIONAL AND CROSS-BORDER CHANGE \\ OF THE ADDRESS OF THE MINOR
}

\author{
María José Valverde MartíneZ \\ Abogada del Ilustre Colegio de Abogados de Murcia
}

Recibido: 16.03.2020 / Aceptado: 03.04.2020

DOI: https://doi.org/10.20318/cdt.2020.5631

\begin{abstract}
Resumen: El cambio de domicilio del menor dentro del territorio español o a otro país distinto al de su residencia habitual, constituye uno de los conflictos más frecuentes entre padres que ejercen conjuntamente la patria potestad. En la solución de estas controversias, resulta irrelevante si los progenitores se encuentran divorciados, fueron pareja de hecho o no llegaron a convivir nunca. Sin embargo, y como decisión fundamental que afecta al interés del menor, el traslado de su domicilio no puede ser acordado de forma unilateral por uno de los progenitores, sino que precisará del consentimiento del otro, y en su defecto, de autorización judicial. Es materia de este este estudio el análisis del régimen jurídico, en Derecho interno español y en DIPr, por el que se rige el cambio de domicilio del menor a través del examen del Auto de la Audiencia Provincial de Barcelona de 9 de octubre de 2019.

Palabras clave: cambio de domicilio del menor, responsabilidad parental, Derecho Internacional Privado, sustracción de menores. Jurisdicción voluntaria.

Abstract: The change of domicile of the minor within the Spanish territory or to another country is one of the most frequent conflicts between parents who jointly exercise parental authority. With regard to these controversies, it is irrelevant if the parents are divorced, were in fact partners or never lived together. Nevertheless, as a fundamental decision that affects the minor's interest, the transfer of his / her domicile cannot be unilaterally decided by one parent. It requires the agreement of both parents. Failing that, a judicial authorization is required prior to a minor's domicile change. This study focuses on is the legal rules governing the minor's transfer of domicile both under Spanish domestic law and in private international law. The Order of October 9, 2019 rendered by the Court of Appeal of Barcelona is one of the most useful examples to look into the different steps of the minor's change of domicile form a legal perspective.
\end{abstract}

Keywords: change of domicile of the minor, parental authority, private international law, child abduction. Voluntary jurisdiction.

Sumario: I. Introducción. La movilidad nacional e internacional del domicilio del menor. II. Un ejemplo de litigación en relación al cambio de domicilio del menor. El Auto de la Audiencia Provincial de Barcelona de 9 de octubre de 2019. 1. Los hechos. Cambio unilateral, decidido por la madre, de domicilio del menor. 2. La reacción del padre. Modificación de medidas a través de la Ley de jurisdicción voluntaria. II. Marco normativo. Titularidad del derecho a precisar el domicilio del menor. 1. Casos internos. Cambios de domicilio del menor dentro del territorio español. A) Personas 
titulares del derecho a determinar el lugar del domicilio del menor. B) Decisiones relevantes en la vida del menor. Cambio del domicilio del menor e intervención decisión judicial Personas titulares del derecho a determinar el lugar del domicilio del menor. 2. Casos internacionales. Cambio de domicilio del menor de país a país. A) Ley aplicable a la determinación de la persona que decide el cambio del domicilio transfronterizo del menor. B) Reglas materiales de segundo escalón e interés del menor en los cambios transfronterizos de domicilio. C) El traslado domicilio del menor, tácitamente consentido, de un país a otro. III. Libertad de circulación y residencia de los ciudadanos. Intereses en presencia: libertad de movimientos del progenitor, libertad de movimientos del menor de edad. El interés superior del menor. 1. Marco constitucional español. La libertad de circulación, un derecho fundamental. 2. El interés del menor y el cambio del domicilio del menor. Criterios para su determinación y valoración judicial. A) Casos internos. La jurisprudencia toma el poder. El Tribunal Supremo, maker of rules. B) Casos internacionales. La regla material corrige a la regla conflictual a través del interés del menor. IV. Perspectiva procedimental para la autorización / desautorización judicial del cambio de domicilio del menor. V. Reflexiones finales. Europeizar el Derecho español en interés del menor.

\section{Introducción. La movilidad nacional e internacional del domicilio del menor}

1. La sociedad del siglo XXI ha experimentado numerosos cambios respecto a la sociedad del siglo anterior. Es una sociedad globalizada, más dinámica, líquida, en la que la circulación de personas por motivaciones distintas se ha hecho habitual e ininterrumpida. En este nuevo modelo de sociedad, las estructuras familiares también han evolucionado y se han impregnado de nuevas formas de convivir y relacionarse, alejadas en numerosas ocasiones de formas tradicionales y más estáticas, en las que la vida familiar se iniciaba en una determinada ciudad, en un concreto país, y permanecía invariable incluso al surgir la crisis matrimonial. La familia cambia de forma y de estructura y lo hace en un escenario internacional, transfronterizo y mundializado ${ }^{1}$.

2. Ante este cambio de paradigma social, es usual y frecuente que un proyecto de vida en común pueda ponerse en marcha a través de matrimonios mixtos o uniones de hecho formadas por personas de distintos países. A su vez, y dentro del mismo escenario de movilidad de las personas, parejas constituidas por personas de una misma nacionalidad pueden plantearse establecer su domicilio, y el de la totalidad de la unidad familiar, en otro u otros países. Y esta realidad de movilidad familiar también tiene su reflejo en situaciones internas del territorio español en las que se observa la creciente formación de parejas que deciden arraigar la unidad familiar en ciudades distintas a las de origen, fundamentalmente por motivos de falta de empleo en sus propias localidades o con el propósito de promocionar profesionalmente. Familias distintas con valores diferentes exigen respuestas jurídicas particulares, como ha defendido L. DE ALMEIDA².

3. Los conflictos derivados de esta creciente movilidad de las familias surgen, unas veces, cuando sobreviene la crisis matrimonial o la crisis en la convivencia de la pareja; otras veces, después del divorcio o tras la ruptura efectiva de la unión de hecho y siendo vigentes las medidas paterno-filiares que se adoptaron judicialmente ante la situación de crisis familiar. En este contexto, caracterizado por

\footnotetext{
${ }^{1}$ Este proceso dinámico y multiforme puede seguirse en numerosos estudios, como, ad ex. el volumen colectivo AA.VV (a cura di Grazia Ofelia Cesaro, Paola Lovati e Gennaro Mastrangelo), La famiglia si trasforma. Status familiari costituiti all'estero e loro riconoscimento in Italia, tra ordine pubblico ed interesse del minore, Franco Angeli Editore, 2014; C. Althammer, "Das Konzept der Familie im europäischen internationalen Familienrecht", en S. ARNold (HRSG.), Grundfragen des europäischen Kollisionsrechts, Tübingen, Mohr Siebeck, 2016, pp. 1-21; A. Benedetti / L. CARPANETo / I. QueIrolo, Le nuove famiglie tra globalizzazione e identitá statuali (Seminario di alta formazione internazionale, Imperia, 10 maggio 2013), 2014; D. Hodson, "Globalisation of adjudication in international family law: serving international families by producing international solutions", en International and national perspectives on child and family law: essays in honour of Nigel Lowe, Cambridge, Intersentia, 2018, pp. 153-165.

2 L. DE Almeida, "Rise and fall of the classic concept of private law: lessons from the legal consciousness of European private law", DESC - Direito, Economia e Sociedade Contemporânea, vol. 1, n. 1 | p. 95-128 | Jul/Dez 2018, pp. 96-128.
} 
situaciones de hecho muy variadas y heterogéneas, los cambios de domicilio de los hijos menores propiciados por uno de los progenitores, -frecuentemente por el progenitor custodio y en menor número de ocasiones por el no custodio-, son cada vez más habituales. Dichos cambios de domicilio se verifican tanto dentro del territorio español como de un país a otro.

4. Una vez producida la ruptura del vínculo de pareja, ya sea por divorcio o por cese de la convivencia de la unión de hecho, no es extraño que uno de los miembros de la pareja desee iniciar junto con sus hijos menores una nueva vida en lugares distintos a los que se asentó inicialmente el núcleo familiar, bien por motivos de oportunidad laboral, bien por falta de arraigo o de vínculos culturales o sociales en el lugar del domicilio familiar, bien por la necesidad de cambiar de vida o incluso por haber formado una nueva familia con otra persona residente en una población distinta, o en un país diferente. Puede que se trate de un traslado de domicilio definitivo o que simplemente obedezca a situaciones de carácter temporal, como la realización de un proyecto laboral concreto, o la enfermedad de un familiar cercano que vive en otro lugar, o el cursar estudios por un periodo de tiempo determinado. La realidad es multiforme y supera toda imaginación.

5. En el marco de las controversias que suscita el cambio de domicilio de los menores de edad cuando ya se han adoptado y están vigentes medidas judiciales relativas a la guarda y custodia del menor y al régimen de visitas a favor del progenitor no custodio, muy bien ha mostrado M. HERRANZ BALLESTEROS, son numerosas las resoluciones judiciales que han tenido que pronunciarse al respecto ${ }^{3}$. No resulta sencillo proporcionar una solución justa a supuestos tan complejos con diferentes intereses enfrentados y sometidos a circunstancias de hecho excepcionales, de modo que es muy cierto lo que escriben los juristas anglosajones: hard cases make bad law. Es decir: los casos extremos son malos ejemplos para crear normas jurídicas generales ${ }^{4}$.

\section{Un ejemplo de litigación en relación al cambio de domicilio del menor. El Auto de la Audiencia Provincial de Barcelona de 9 de octubre de 2019.}

\section{Los hechos. Cambio unilateral, decidido por la madre, de domicilio del menor}

6. Interesante y útil resulta analizar el cambio de domicilio del menor al hilo de un reciente caso concreto. Se trata del Auto de la Audiencia Provincial de Barcelona de 9 de octubre de 20195. La resolución judicial que se analiza resuelve el caso de una solicitud de jurisdicción voluntaria planteada por un padre ante un Juzgado de Primera Instancia español, en la que interesa que no se autorice el cambio de domicilio de su hijo menor realizado por la madre dentro del territorio español, en concreto

\footnotetext{
3 Vid. M. Herranz Ballesteros, “Análisis del consentimiento del progenitor al desplazamiento o la retención del menor en un estado distinto al de su residencia habitual. Su interpretación en el auto de la Audiencia Provincial Barcelona (Sección $18^{\mathrm{a}}$ ) de 27 de noviembre", $C D T, 11,2$, Octubre 2019, pp. 641-651; M. Herranz Ballesteros, "Aproximación al procedimiento prejudicial de urgencia a través de la protección internacional de menores”, en A. Cebrián SALVAt/I. Lorente Martínez (Dir.), Protección de menores y Derecho Internacional Privado, Granada, Editorial Comares, 2019, pp. 171-189; M. Herranz BallesTERos, "Traslado del domicilio del menor en la jurisprudencia del Tribunal Supremo", en A.-L. Calvo Caravaca/J. Carrascosa GonzÁLEz (Dir.), El Tribunal Supremo y el Derecho Internacional Privado, vol. 2, Murcia, Rapid Centro Color S.L., 2019, pp. 567-586; M. Herranz Ballesteros, "La sustracción internacional de menores. A propósito de la STC 120/2002, de 20 mayo 2002, RDP, octubre 2002, pp. 754-770; ID., "El Reglamento 2201/2003. Alcance de la reforma en materia de sustracción internacional de menores en el espacio judicial europeo", Aranzadi Civil, nov.2004, pp. 13-31.

${ }^{4}$ Este famoso adagio legal se remonta, al menos, al año 1837. El juez Oliver Wendell Holmes Jr. lo empleó expresamente en el muy famoso caso Northern Securities Co. v. United States (1904), 193 U.S. 197 (1904), cuyo texto puede leerse en https:// supreme.justia.com/cases/federal/us/193/197/. Desde entonces esta máxima legal es citada con extrema frecuencia. El origen de la misma puede verse muy bien explicado en J. Chipman Gray, The nature and sources of the law, Columbia University Press, 1909, p. 263 y su dearrollo, implicaciones y limites pueden explorarse en el sugestivo trabajo de F. SCHAUER, "Do cases make bad law?", The University of Chicago Law Review, 2006, pp. 883-918.

${ }^{5}$ AAP Barcelona 9 octubre 2019 [ECLI:ES:APB:2019:7737A] y [CENDOJ 08019370182019200354].
} 
que no se apruebe el cambio de domicilio del menor desde una localidad de Cataluña a un pueblo de la provincia de Cuenca.

El traslado de domicilio del hijo menor de edad ya se había consumado al solicitar el padre que se desautorizara el mismo, es decir, se había hecho efectivo por decisión unilateral de la madre, sin mediar el consentimiento del padre y sin existir autorización judicial al efecto. El conflicto entre los progenitores relativo a la fijación del domicilio del menor ya existe cuando se acude a la autoridad judicial.

7. Como antecedente de este conflicto, es preciso subrayar que los progenitores habían sido pareja de hecho en el pasado, y de dicha unión nació el hijo común de ambos. Posteriormente, producido el cese de la convivencia de la pareja, mediante sentencia de 17 de noviembre de 2015, un Juzgado de Primera Instancia español homologó el convenio regulador de medidas paterno-filiares suscrito por ambos. En el convenio de medidas se acordó por el mutuo acuerdo de las partes establecer una guarda materna y visitas a favor del padre de fines de semana alternos y mitad de periodos vacacionales. De la misma manera, en el convenio de medidas relativas al menor se designó el domicilio donde madre e hijo residirían dentro del territorio español.

8. El tiempo pasa y siempre parece que transcurre más deprisa cuando se trata de litigios que afectan a la familia y a los menores. En noviembre del año 2018 la madre decidió de forma unilateral trasladar su domicilio a la provincia de Cuenca. Comunicó al padre por correo certificado que, por haber recibido una oferta laboral, se trasladaba con el hijo de ambos a otro domicilio distinto al que venía residiendo con el menor. Destino: Cuenca. Para acreditar su nueva situación laboral, la madre acompañó a su comunicación de cambio de domicilio una nómina como limpiadora a tiempo parcial en un geriátrico en la población conquense de su nueva residencia. La madre no contaba con el consentimiento del padre a dicho traslado del domicilio del menor, y tampoco instó autorización judicial para llevar a efecto dicho traslado domicilio del hijo menor.

\section{La reacción del padre. Modificación de medidas a través de la Ley de jurisdicción voluntaria}

9. Para resolver el conflicto suscitado entre los progenitores del menor en torno al cambio de domicilio de éste, el procedimiento elegido por el padre fue el de jurisdicción voluntaria, regulado en los artículos 85 y 86 de la Ley 15/20156.

10. En el asunto objeto de estudio, una vez que fue admitida a trámite por el juzgado español la solicitud de jurisdicción voluntaria instada por el padre, la madre se personó en el procedimiento judicial el día señalado para la celebración de la vista. En dicho acto, solicitó que se le permitiera el cambio de residencia ya consumado por motivo de su situación de necesidad, puesto que en la población catalana donde tenían establecido su domicilio madre e hijo, ella se encontraba desempleada y, por su parte, el padre tampoco abonaba la pensión de alimentos. En consecuencia, la madre no podía hacer frente a la cuota mensual de la hipoteca de su vivienda. Asimismo, la madre alegó en el acto de la vista que el padre había dejado de visitar al niño, incumpliendo con ello el régimen de visitas acordado en el convenio regulador homologado por la sentencia de medidas paterno-filiares.

11. Seguidos los preceptivos trámites del procedimiento de jurisdicción voluntaria, mediante auto de 16 de enero de 2019 dictado por el Juzgado de Primera Instancia español que conocía del caso desestimó la solicitud del padre de prohibición de cambio de domicilio del menor y de centro escolar y otorgó a la madre del menor la facultad de decidir sobre el traslado del domicilio del menor. Dicha resolución se fundamenta, en síntesis, en que la precaria situación económica de la madre, unida a la nula colaboración del padre en la crianza del hijo así como el incumplimiento del régimen de visitas por

\footnotetext{
${ }^{6}$ Ley 15/2015, de 2 de julio, de la Jurisdicción Voluntaria (BOE núm. 158 de 3 julio 2015).
} 
el progenitor no custodio, son elementos suficientes que justifican que el cambio de domicilio llevado a efecto por la madre sea considerado pertinente en sede judicial.

12. Posteriormente, el padre recurrió en apelación el auto dictado en la primera instancia ante la Audiencia Provincial de Barcelona por entender que la decisión unilateral de la madre de cambiar el domicilio del menor alejaba a éste último de su entorno social y natural.

13. La historia continúa, pues finalmente, mediante auto de la Audiencia Provincial de Barcelona de 9 de octubre de 2019 se estima el recurso de apelación interpuesto por el padre. La Audiencia acuerda no autorizar el cambio de residencia del menor a la provincia de Cuenca, por ser contrario a la sentencia de 17 de noviembre de 2015 que estableció las medidas paterno filiares relativas al menor tras producirse la ruptura de la convivencia de los progenitores.

14. La resolución dictada en apelación por la Audiencia Provincial de Barcelona en favor de las pretensiones del padre y en contra del nuevo domicilio del menor, concede, sin embargo, con carácter cautelar y por treinta días, permiso para que el menor mantenga su residencia en su nueva ubicación situada en Cuenca. Se dispone, también, que transcurrido dicho plazo de treinta días sin que ninguna de las partes haya promovido demanda de modificación de efectos de sentencia con petición, en su caso, de la prolongación del permiso otorgado, será vigente la sentencia de 17 de noviembre de 2015 en sus propios términos, con los posibles apercibimientos establecidos en el art. 776 LEC. Esto es, se volverá a la situación inicial y el menor deberá retornar a su domicilio en Cataluña. Como medida también cautelar, el auto de la Audiencia Provincial de Barcelona de 9 de octubre de 2019 acuerda que el padre tenga derecho a visitar a su hijo en su domicilio de la provincia de Cuenca.

15. Resulta útil, a la par que conveniente, analizar, en el presente trabajo la fundamentación jurídica del auto de la Audiencia Provincial de Barcelona de 9 de octubre de 2019 que propició la denegación de autorización judicial del cambio de domicilio del menor, así como el régimen jurídico que debe ser observado en las modificaciones de domicilio de los menores, tanto si estos traslados se efectúan dentro del territorio español, como si el desplazamiento tiene carácter transfronterizo.

\section{Marco normativo. Titularidad del derecho a precisar el domicilio del menor.}

\section{Casos internos. Cambios de domicilio del menor dentro del territorio español.}

\section{A) Personas titulares del derecho a determinar el lugar del domicilio del menor.}

16. La primera cuestión que debe tenerse presente, como señalan C. GonZÁlez BeILfuss y E. RodRíGUEZ PINAU, es la determinación de las personas que son titulares del derecho a precisar el lugar donde los hijos menores de edad tienen su domicilio 7 . En el caso objeto del auto de la Audiencia Provincial de Barcelona de 9 de octubre de 2019, se aplicó el Código Civil Catalán. Éste establece con claridad quiénes son los titulares para decidir el domicilio de los hijos menores de edad, ya que conforme al art. 236-17 y 233-8 del Código Civil Catalán, "[l] a facultad de decidir el lugar de residencia de los hijos menores forma parte del contenido de la potestad parental, cuyas responsabilidades no quedan alteradas por la nulidad, divorcio o separación de los padres (art. 233-8 CCCat) y que corresponde a ambos padres".

Añade el auto citado que la decisión de trasladar a los menores de domicilio es una cuestión sujeta a ciertas condiciones. En concreto, el art. 236-11.6 del Código civil catalán exige "el consentimiento

\footnotetext{
${ }^{7}$ C. GonzÁlez Beilfuss, "El traslado lícito de menores: las denominadas Relocation Disputes", REDI, (2010), 2, pp. $52-$ 75; E. Rodríguez Pinau, "Revisión de la atribución de la custodia y la reubicación internacional del menor en interés superior del menor: Comentario a la STS de 18 de enero 2017 (RJ 2017, 343), Cuadernos Cívitas de Jurisprudencia Civil, enero-abril 2018, pp. 9-21.
} 
expreso o tácito del otro progenitor o, en otro caso, autorización judicial para variar el domicilio de los hijos si ello los aparta de su entorno habitual"'.

17. En Derecho español, por el hecho biológico del nacimiento o por razón de adopción, los progenitores asumen una serie de funciones o deberes en relación a sus hijos menores de edad que forman parte de lo que se denomina, en terminología tradicional heredada del Derecho Romano, "patria potestad".

18. Tal y como apunta A.J. Pérez Martín, resulta muy llamativo que el legislador español siga empleando el término "patria potestad" cuando en la legislación europea se ha acuñado otro término distinto, -más ilustrativo, más amplio y más centrado en la persona del menor y menos en la propiedad de los padres-, y que permitiría una aplicación uniforme del Derecho de la Unión Europea, esto es, el concepto de "responsabilidad parental sobre los hijos comunes"9. Significativo es, también, que ciertas legislaciones civiles autonómicas españolas utilicen todavía hoy otros términos equivalentes a la patria potestad, como "potestad parental" en el caso de Cataluña, o "autoridad familiar" en Aragón.

19. El art. 154 del Código civil español dispone que los hijos no emancipados están bajo la potestad de sus progenitores, que se ejercerá en beneficio de los hijos, de acuerdo con su personalidad y comprende los deberes y facultades siguientes: $1^{\circ}$ ) Velar por ellos, tenerlos en su compañía, alimentarlos, educarlos y procurarles una formación integral. $2^{\circ}$ ) Representarlos y administrar sus bienes.

20. Los preceptos legales que regulan la patria potestad en el Derecho Civil común español, o los que rigen la potestad parental en el caso de Cataluña, no establecen diferencias en el ejercicio de la patria potestad por los padres dependiendo de si existe vínculo matrimonial entre ellos, si están separados, divorciados o incluso si constituyen una unión de hecho. La separación, el divorcio, la crisis de pareja de los progenitores, e incluso la falta de convivencia de los mismos, en principio, no altera el contenido de los derechos y deberes que forman parte integrante del núcleo central de la patria potestad. En consecuencia, la decisión del cambio de domicilio del menor, cualquiera que el vínculo que tengan o hayan tenido los padres, quedará sometida a la decisión conjunta de ambos padres $\mathrm{y}$, en su defecto, precisará de autorización judicial.

21. Con arreglo al art. 156 del Código Civil español, en situaciones de normalidad, la patria potestad se ejercerá conjuntamente por ambos progenitores o por uno solo con el consentimiento expreso o tácito del otro. En la práctica, cuando se presenta una demanda de separación o divorcio o una demanda encaminada a regular la crisis de una pareja de hecho, lo habitual es que se solicite como medida que la patria potestad sea atribuida y ejercida conjuntamente por ambos progenitores. Esta práctica habitual presenta ciertas salvedades. Así es, puesto que, en determinadas circunstancias, se peticiona la privación de la patria potestad en relación con uno de los progenitores, para que sea atribuida de forma exclusiva al otro progenitor. Esta medida se encuentra reservada para los casos más graves de incumplimiento de los deberes

\footnotetext{
${ }^{8}$ Artículo 233-8 del Código civil catalán: "Responsabilidad parental. 1. La nulidad del matrimonio, el divorcio o la separación judicial no alteran las responsabilidades que los progenitores tienen hacia sus hijos de acuerdo con el artículo 23617. En consecuencia, estas responsabilidades mantienen el carácter compartido y, en la medida de lo posible, deben ejercerse conjuntamente". Artículo 236-17 del Código civil catalán: "Relaciones entre padres e hijos. 1. Los progenitores, en virtud de sus responsabilidades parentales, deben cuidar de los hijos, prestarles alimentos en el sentido más amplio, convivir con ellos, educarlos y proporcionarles una formación integral. Los progenitores tienen también el deber de administrar el patrimonio de los hijos y de representarlos. 2. Los progenitores determinan el lugar o lugares donde viven los hijos y, de forma suficientemente motivada, pueden decidir que residan en un lugar diferente al domicilio familiar". Artículo 136.-11 del Código civil catalán: "(....) 6. El progenitor que ejerce la potestad parental, salvo que la autoridad judicial disponga otra cosa, necesita el consentimiento expreso o tácito del otro para decidir el tipo de enseñanza de los hijos, para cambiar su domicilio si eso los aparta de su entorno habitual y para realizar actos de administración extraordinaria de sus bienes. Se entiende que el consentimiento se ha conferido tácitamente si ha vencido el plazo de treinta dias desde la notificación, debidamente acreditada, que se haya efectuado para su obtención y el progenitor que no ejerce la potestad no ha planteado el desacuerdo según lo establecido por el artículo 236-13".

9 A.J. Pérez Martín, Tratado de Derecho de Familia. Tomo I, volumen I: Procedimiento Contencioso de separación, divorcio y nulidad. Uniones de hecho. Otros procedimientos contenciosos. Aspectos sustantantivos, Lex Nova, Madrid, pp. 165 y ss.
} 
paterno-filiares por uno de los padres del menor (art. $170 \mathrm{CC}$ ). Los preceptos citados del Código civil español operan como una verdadera "Constitución española en el sector de las relaciones paterno-filiales", idea muy presente en la doctrina francesa, y en particular en el inspirador ensayo de R. CABRILLAC ${ }^{10}$.

22. Tal y como señala el citado auto de la Audiencia Provincial de Barcelona, en los casos en los que exista una resolución judicial previa en la que se haya acordado un determinado sistema de guarda y custodia y, al mismo tiempo se haya establecido, de forma directa o indirecta, el lugar de residencia de un menor de edad, el cambio de residencia de éste último producido de forma sobrevenida (por ejemplo si el titular de la guarda y custodia, por cualquier motivo, lo provoca) debe quedar sometido a la autorización del otro progenitor el traslado del menor. El consentimiento del otro progenitor es una facultad integrada en la titularidad de la patria potestad, puesto que si no se le ha privado de ella, permanece incólume a favor de los dos padres.

\section{B) Decisiones relevantes en la vida del menor. Cambio del domicilio del menor e intervención de- cisión judicial Personas titulares del derecho a determinar el lugar del domicilio del menor}

23. El ejercicio conjunto de la patria potestad lleva consigo que todas las decisiones de importancia que deban adoptarse en relación a los hijos serán tomadas de común acuerdo entre los progenitores y nunca de forma unilateral por uno de ellos, esto es, sin que medie el consentimiento del otro. En tal sentido, y como han subrayado con carácter general B.G. RoBBins / E. KISER, las normas jurídicas españolas y europeas desarrollan una labor de compliance dirigida a los progenitores, de modo que interioricen el valor del interés del menor y traten de alcanzar un punto común de acuerdo a la hora de fijar el domicilio del menor ${ }^{11}$. Ahora bien, si tal acuerdo no se alcanza y persiste la discrepancia entre los padres, será el juez el que acuerde lo que es procedente, que no es otra cosa que atribuir a uno u otro progenitor la decisión sobre la cuestión planteada, es decir, el juez no acuerda qué debe hacerse, sino que atribuye la facultad de decidir al padre o a la madre (art. $156 \mathrm{CC}$ ).

24. No obstante lo anterior, la duda surge respecto a cuáles son las decisiones importantes que han de ser adoptadas de común acuerdo por los progenitores. Y para dar respuesta a esta pregunta, tanto la jurisprudencia y como la doctrina civilista mayoritaria distingue entre: a) actos de ejercicio ordinario de la patria potestad, que puede realizar uno solo de los progenitores, y en concreto, el progenitor que ejerce la guarda y custodia de hecho o en virtud de resolución judicial, sin necesidad de solicitar el consentimiento del otro; b) actos de ejercicio extraordinario de la patria potestad, para los cuales es preciso el consentimiento de ambos progenitores o, en su defecto, resolución judicial.

Los actos de ejercicio extraordinario de la patria potestad se refieren a las decisiones más relevantes e importantes que pueden adoptarse en la vida de un menor y que no pueden calificarse como ordinarias o habituales en el ámbito de la familia por resultar "excepcionales conforme a los usos sociales". Como es obvio, la elección del lugar de domicilio / residencia habitual de un menor, así como el traslado del mismo a otro domicilio son decisiones que exceden del contenido ordinario de la patria potestad y constituyen "actos de ejercicio extraordinario" de la misma. Se trata de decisiones no ordinarias ni habituales. Son decisiones que no resultan "conforme al uso social", según establece el art. 156 del Código Civil, de modo que no pueden ser adoptadas por uno sólo de los progenitores, sino que ordinaria y habitualmente, serán realizados por ambos progenitores por implicar decisiones de importante trascendencia y repercusión en la vida del menor ${ }^{12}$.

\footnotetext{
${ }^{10}$ R. Cabrillac, "Le Code Civil est-il la véritable Constitution de la France?", Revue Juridique Thémis, n. 39, tomo 3, 1994, Québec. pp. 245-269.

${ }^{11}$ B.G. RobBIns / E. KISER, "Culture, Coercion, and Compliance", septiembre 2018, en https://ssrn.com/abstract=3264020 or http://dx.doi.org/10.2139/ssrn.3264020.

12 J.P. González del Pozo, "Ponencia: Los Expedientes de Jurisdicción Voluntaria de adopción de las medidas previstas en los artículos 156 y 158 CC", en IV Jornadas de Familia de Murcia, ICAMUR y AEAFA, septiembre de 2018, pp.52-55.
} 
25. La sentencia ${ }^{0}$ 642/2012, del Tribunal Supremo, Sala 1a , de lo Civil, de 26 de octubre de 2012, constituye todo un referente de primera magnitud para fijar el régimen jurídico del el cambio de domicilio del menor y para calificarlo como un verdadero y auténtico "acto de ejercicio extraordinario de la patria potestad". Esta sentencia indica que la guarda y custodia de los menores "deriva de la patria potestad y de la patria potestad, entre otras cosas, deriva la fijación del domicilio familiar, según dispone el artículo 70 del Código Civil, para dar cumplimiento a lo previsto en el artículo 68 del Código Civil, respecto de la obligación de vivir juntos. La ruptura matrimonial deja sin efecto la convivencia y obliga a los progenitores a ponerse de acuerdo para el ejercicio de alguna de estas facultades que traen causa de la patria potestad, entre otra la de fijar el nuevo domicilio y, como consecuencia, el de los hijos que se integran dentro del grupo familiar afectado por la ruptura coincidente por lo general con el de quien ostenta la guarda y custodia. Estamos, sin duda, ante una de las decisiones más importantes que pueden adoptarse en la vida del menor y de la propia familia, que deberá tener sustento en el acuerdo de los progenitores o en la decisión de uno de ellos consentida expresa o tácitamente por el otro, y solo en defecto de este acuerdo corresponde al juez resolver lo que proceda previa identificación de los bienes y derechos en conflicto a fin de poder calibrar de una forma ponderada la necesidad y proporcionalidad de la medida adoptada, sin condicionarla al propio conflicto que motiva la ruptura. Es cierto que la Constitución Española, en su artículo 19, determina el derecho de los españoles a elegir libremente su residencia, y a salir de España en los términos que la ley establezca. Pero el problema no es este. El problema se suscita sobre la procedencia o improcedencia de pasar la menor a residir en otro lugar, lo que puede comportar un cambio radical tanto de su entorno social como parental, con problemas de adaptación. De afectar el cambio de residencia a los intereses de la menor, que deben de ser preferentemente tutelados, podría conllevar, un cambio de la guarda y custodia" (énfasis añadido) ${ }^{13}$. Esta línea es constante, firme y segura en la jurisprudencia del Tribunal Supremo ${ }^{14}$.

26. Algunas Audiencias Provinciales españolas, en una interpretación divergente de la jurisprudencia pacífica del Tribunal Supremo, han entendido, erróneamente, que los cambios de domicilio del menor pueden ser acordados por el progenitor custodio, en reflejo de la libertad de residencia, domicilio y deambulación recogidas en la Constitución española. Sin embargo, la doctrina del TS es más que clara al respecto: "de la patria potestad deriva igualmente el derecho de guarda y custodia, de forma que, tanto el progenitor titular del derecho de custodia como aquel que se ve privado de la misma puede participar en la toma de decisiones fundamentales al interés superior del menor. Una de ellas es la que concierne a su traslado o desplazamiento en cuanto lo aparta de su entorno habitual e incumple el derecho de relacionarse con el padre o madre no custodio" 15 .

Es por ello que resulta imprescindible tener presente en todo momento del discurso jurídico relativo al cambio de domicilio del menor, la distinción entre los conceptos jurídicos de "patria potestad" y "guarda y custodia". Así lo expresa de modo ejemplar la sentencia de la Audiencia Provincial de Castellón de 10 de septiembre de 2010, que precisa: "la atribución de la guarda y custodia sobre un menor no conlleva que el titular de aquella tenga la libérrima facultad de decidir, sin limitaciones, el domicilio del menor sometido a dicha guarda y custodia. El derecho fundamental .......del progenitor custodio a elegir su libre residencia no puede desvincularse de los intereses del menor que tan drásticamente pueden verse afectados... un cambio de domicilio relevante para la vida del menor es una cuestión que debería ser decidida libremente por los dos cotitulares de la patria potestad, y, en defecto de acuerdo, por la autoridad judicial"'16.

\footnotetext{
${ }^{13}$ STS 26 octubre 2012, no 642/2012 [CENDOJ: 28079110012012100608].

14 Vid. STS 485/2015 de 10 septiembre 2015 [ECLI: ES:TS:2015:3796]; STS 748/2014 de 11 diciembre 2014 [ECLI: ES:TS:2014:5099]; STS 200/2016 de 31 marzo 2016 [ECLI: ES:TS:2016:1419]; STS 664/2015 de 19 noviembre 2015 [ECLI: ES:TS:2015:492]; STS 230/2018 de 18 abril 2018 [ECLI: ES:TS:2018:1383].

${ }^{15}$ M. Herranz Ballesteros, "Traslado del domicilio del menor en la jurisprudencia del Tribunal Supremo", en A.-L. Calvo Caravaca/J. Carrascosa González (Dir.), El Tribunal Supremo y el Derecho Internacional Privado, vol. 2, Murcia, Rapid Centro Color S.L., 2019, pp. 567-586.

${ }^{16}$ SAP Castellón 10 septiembre 2010 [CENDOJ 12040370022010100334].
} 


\section{Casos internacionales. Cambio de domicilio del menor de país a país}

\section{A) Ley aplicable a la determinación de la persona que decide el cambio del domicilio transfronte- rizo del menor}

27. En los asuntos con elemento internacional, debe tenerse presente que están en vigor para España diversos instrumentos legales que regulan tanto la competencia judicial internacional de las autoridades públicas para acordar medidas de protección de los niños y los menores, como la ley aplicable a dichas medidas. Por lo que se refiere a la eficacia extraterritorial de decisiones relativas a la responsabilidad parental y protección de menores, el instrumento estrella es, qué duda cabe, el Reglamento 2201/2003, de 27 de noviembre regula la competencia judicial internacional y la validez extraterritorial de decisiones en materia civil relativa a la denominada "responsabilidad parental" ${ }^{17}$. El Reglamento no determina la ley aplicable a la responsabilidad parental, ya que ésta se precisa a través del Convenio de La Haya de 19 de octubre 1996 (protección de niños), y, en su caso, a través del art. 9.6 del Código Civil español.

28. El Reglamento 2201/2003 recoge el concepto de "responsabilidad parental" y especifica que comprende "los derechos y obligaciones conferidas a una persona física o jurídica en virtud de una resolución judicial, por ministerio de la ley o por un acuerdo con efectos jurídicos, en relación con la persona o los bienes de un menor" (art.1.2, 1.3 y 2.7). Como señala J. CARRASCOSA GonZÁlez, la responsabilidad parental es un concepto muy extenso que incluye: a) el derecho de custodia y el derecho de visita ; b) la tutela, la curatela y otras instituciones análogas; c) la designación y las funciones de toda persona u organismo encargado de ocuparse de la persona o de los bienes del menor, de representarlo o de prestarle asistencia; d) el acogimiento del menor en una administración, conservación o disposición de sus bienes; f) las medidas de Derecho Público relativas al menor ${ }^{18}$.

29. La responsabilidad parental se configura en el Reglamento 2201/2003 como concepto autónomo, un concepto europeo que no puede ni debe ser definido con arreglo a la Ley de ningún Estado miembro concreto. Incluye la patria potestad regulada en el Derecho Civil español pero no debe ser identificado con ella. Es decir, que la patria potestad está incluida en el término y concepto de "responsabilidad parental" pero ésta es mucho más que la noción española de "patria potestad". Para el Reglamento 2201/2003, la patria potestad es una medida más, entre otras muchas, cubierta por el concepto de "responsabilidad parental".

30. Una vez definida la responsabilidad parental, es el Convenio de La Haya, de 19 de octubre de 1996 el que determina la "ley aplicable" a la protección de niños mediante diversas normas de conflicto de leyes ${ }^{19}$. Según dicho convenio, la Ley aplicable al ejercicio de la responsabilidad parental (facultades, derechos y obligaciones de los sujetos que la ostentan), y por lo tanto a las cuestiones relativas a los cambios de domicilio del menor es la Ley del Estado de la residencia habitual del niño (art. 17 in primis $\mathrm{CH}$ 1996) ${ }^{20}$. En caso de que el menor cambie de país de residencia habitual, la ley aplicable será la de su nueva residencia habitual (art. 17 in fine CH 1996). Por tanto, en caso de conflicto móvil, rige la Ley nueva la Ley del nuevo país de residencia habitual del menor. En otras palabras: cambio de residencia habitual de un país a otro significa cambio de Ley aplicable a la responsabilidad parental.

${ }_{17}$ Reglamento (CE) 2201/2003 del Consejo de 27 noviembre 2003 relativo a la competencia, el reconocimiento y la ejecución de resoluciones judiciales en materia matrimonial y de responsabilidad parental, por el que se deroga el Reglamento (CE) no 1347/2000 (DOUE L 338 de 23 diciembre 2003) (Reglamento Bruselas II-bis).

18 A.-L. Calvo Caravaca / J. Carrascosa González (Directores), Derecho internacional privado, vol. II, 18 a edición, Comares, Granada, 2018, pp. 542-543.

${ }_{19}$ Convenio relativo a la competencia, la ley aplicable, el reconocimiento, la ejecución y la cooperación en materia de responsabilidad parental y de medidas de protección de los niños, hecho en La Haya el 19 octubre 1996 (BOE núm. 291 de 2 diciembre 2010).

${ }^{20}$ J. PIRrung, "EuEheVO und HKÜ: Steine statt Brot? - Eilverfahren zur Frage des gewöhnlichen Aufenthalts eines vierbis sechsjährigen Kindes (EuGH, S. 239)", IPRax, 2015-3, pp. 207-212. 
31. Son diversas las cuestiones, señalan A.-L. Calvo Caravaca / J. Carrascosa González, que deben ser ponderadas en los supuestos de traslados de domicilio del menor a otro país y ello al hilo de la ya abundante jurisprudencia española en la materia ${ }^{21}$.

\section{B) Reglas materiales de segundo escalón e interés del menor en los cambios transfronterizos de domicilio}

32. En primer lugar, y como ya se ha avanzado, la Ley que regula la patria potestad o la responsabilidad parental, según lo dispuesto en el Convenio de La Haya, será la que determine, igualmente, la cuestión de precisar a qué cónyuge y en qué circunstancias corresponde decidir dónde debe ubicarse el "domicilio del menor" y si éste puede ser trasladado a otro país, ya de modo permanente o de modo transitorio o temporal.

33. En segundo término, debe tenerse presente que en Derecho civil español, ya en un nivel de segundo escalón de la norma de conflicto, la fijación del domicilio de los hijos no puede dejarse a la sola y libre voluntad del progenitor custodio ${ }^{22}$. Criterio imprescindible será siempre el "interés del menor", de manera que un traslado al extranjero de un menor de edad decidido unilateralmente por el progenitor que ostenta la exclusiva custodio del mismo, podría dañar el derecho del mismo a relacionarse con su otro progenitor y podría vulnerar el derecho del menor a su protección y su cuidado, necesarios para su bienestar ${ }^{23}$. En definitiva, el progenitor custodio debe ejercer, siempre, su derecho a la fijación del domicilio del menor en interés de éste, incluso si el régimen es de custodia compartida ${ }^{24}$

34. En tercer lugar, la fijación del domicilio del menor en un concreto lugar y país no puede hacerse depender de la nacionalidad del mismo, porque la cuestión no se centra en proteger a los "nacionales", sino de favorecer al menor considerado como sujeto de Derecho y como persona concreta e individualizada ${ }^{25}$.

35. En cuarto lugar, resultan de especial relevancia los supuestos en los que los titulares de la responsabilidad parental pretenden hacer valer el consentimiento prestado por uno de los progenitores para el cambio de domicilio del menor a otro país distinto al que tenía su residencia habitual. En este sentido, los padres pueden haber pactado un acuerdo para la libre circulación del menor, es decir, pueden haber acordado la "libertad de movimientos del menor", incluyendo sus salidas al extranjero. En consecuencia, de mediar pacto entre los progenitores, no podrá existir "traslado ilícito", pues se trataría de un traslado internacional "libremente consentido" 26 .

${ }^{21}$ A.-L. Calvo Caravaca / J. Carrascosa González (Directores), Derecho internacional privado, vol. II, $18^{a}$ edición, Comares, Granada, 2018, pp. 542-543.

22 SAP Castellón 10 septiembre 2010 [CENDOJ 12040370022010100334]; SAP Castellón 28 noviembre 2012 [CENDOJ 12040370022012100164]; SAP Castellón 6 septiembre 2013 [JUR 2013/349850]; STS 18 enero 2017 [JUR\2017\25003]; SAP Barcelona 17 enero 2018 [ECLI:ES:APB:2018:155]; AAP Barcelona 9 octubre 2019 [ECLI:ES:APB:2019:7737A]; SAP Barcelona 14 noviembre 2019 [ECLI:ES:APB:2019:13677]; SAP Barcelona 6 noviembre 2019 [ECLI:ES:APB:2019:13081]; STSJ Cataluña 14 octubre 2015 [CENDOJ 08019310012015100097].

${ }^{23}$ STS 20 octubre 2014 [CENDOJ 28079110012014100504], en un caso de posible traslado del menor desde España a Brasil: "el cambio de residencia al extranjero del progenitor custodio puede ser judicialmente autorizado únicamente en beneficio e interés de los hijos menores bajo su custodia que se trasladen con el".

${ }^{24} \mathrm{El}$ interés superior de los menores "está por encima del vínculo parental", por lo que "lo mejor o más conveniente para ellos es que sigan bajo la custodia de su madre en Tokio, en un ambiente que no les es extraño pues allí tuvo su residencia habitual la familia durante algunos años" (STS 18 abril 2018 [ECLI:ES:TS:2018:1414], que aborda el caso de unos menores con residencia en Tokio] y también la STS 17 octubre 2018 [ECLI: ES:TS:2018:3527], en la que se analiza un caso en el que el padre de los menores reside en los Estados Unidos.

${ }^{25}$ STS 20 octubre 2014 [CENDOJ 28079110012014100504].

26 SAP Lugo 22 diciembre 2015 [CENDOJ 27028370012015100471]; SAP Asturias 5 julio 2013 [CENDOJ 33024370072013100293]; AAP Madrid 15 octubre 2002 [CENDOJ 28079370222002200281]; SAP Asturias 30 abril 2007 [CENDOJ 33024370072007100172]. 


\section{C) El traslado del domicilio del menor, tácitamente consentido, de un país a otro}

36. ¿Es posible el consentimiento tácito de un progenitor al traslado del domicilio del menor a otro pais? El consentimiento al traslado por parte de un titular del derecho de custodia debe ser un "consentimiento claro, terminante e indubitado", ya que el consentimiento presunto no produce efecto legal alguno ${ }^{27}$. La existencia de un consentimiento tácito podría ser entendida y justificada si existe conocimiento por parte del otro progenitor del traslado y no se opone al mismo; por tanto, no existiría vulneración del derecho de custodia aunque posteriormente el progenitor que tácitamente consintió proteste o manifieste su desacuerdo en relación con dicho traslado, lo que ocurre en numerosas ocasiones ${ }^{28}$.

37. En estos casos de probable consentimiento tácito, deben analizarse las circunstancias concretas del caso en cuestión con el fin de que no exista duda alguna sobre ese traslado "consentido". Un buen práctico del Derecho debería acreditar, por ejemplo, que un padre, una madre y un hijo, los tres de nacionalidad española y con residencia habitual en Washington D.C (EEUU), viajaron a España con la intención de que el menor permaneciera en este último país con la madre al haberse producido la quiebra de la convivencia conyugal y tras ser iniciado un procedimiento de divorcio por los cónyuges. Debería, igualmente, ser probado en este caso que el padre ha facilitado la documentación necesaria para que el menor permanezca en España con la madre, sin que en ningún momento el progenitor objetara que tal documentación se proporcionaría para un tiempo limitado y determinado, así como que ha pagado el viaje en avión a España de la madre y del hijo, sin billete de vuelta. Acreditadas las circunstancias de hecho relatadas, difícilmente podría entenderse que existiera una sustracción ilícita del menor, ya que con sus actos propios ("non venire contra factum propium"), el progenitor habría consentido tácitamente el traslado.

38. En otros supuestos de hecho, si consta un acuerdo entre los titulares de la custodia para trasladar a los menores por un período determinado y dicho acuerdo se infringe, existe "retención ilícita de los menores". En tal supuesto, es aplicable el Convenio sobre los aspectos civiles de la sustracción internacional de menores, hecho en La Haya el 25 octubre 1980 para lograr la restitución del menor al país de su residencia habitual, como ha puesto de relieve la jurisprudencia ${ }^{29}$. De igual manera, si existe acuerdo para trasladar al menor a un país pero se le traslada a otro distinto, el traslado es "no consentido" y por tanto "ilícito" y de nuevo, el citado convenio internacional es aplicable para conseguir el retorno del menor al país de su precedente residencia habitual ${ }^{30}$.

III. Libertad de circulación y residencia de los ciudadanos. Intereses en presencia: libertad de movimientos del progenitor, libertad de movimientos del menor de edad. El interés superior del menor

\section{Marco constitucional español. La libertad de circulación, un derecho fundamental}

39. Los fundamentos de Derecho del auto de la Audiencia Provincial de Barcelona de 9 de octubre de 2019 toman como punto de partida en el derecho de cualquier ciudadano la libertad de residencia y a la libertad de circulación. Ello, en definitiva, supone el reconocimiento a toda persona de la posibilidad de desplazarse libremente de un lugar a otro del territorio nacional, así como de salir y

\footnotetext{
${ }^{27}$ AAP Palencia 20 abril 2018 [ECLI:ES:APP:2018:217]; SAP Pontevedra 2 mayo 2019 [ECLI:ES:APPO:2019:1074].

${ }^{28}$ SAP Pontevedra 17 abril 2018 [ECLI:ES:APPO:2018:354]; SAP Alicante 18 abril 2016 [CENDOJ 030653700920 16100182].

${ }^{29}$ BOE núm.202 de 24 agosto 1987; corr. errores, BOE núm. 155 de 30 junio 1989 y BOE núm.21, de 24 enero 1996. Vid. SAP Murcia 24 mayo 2018 [ECLI:ES:APMU:2018:1395]; SAP S. Cruz Tenerife 10 mayo 2018 [ECLI:ES:APTF:2018:628]; SAP Asturias 15 marzo 2017 [JUR\2017\106546]; SAP Baleares 28 julio 2016 [CENDOJ 07040370042016100256]; SAP Zaragoza 19 enero 2016 [CENDOJ 50297370022016100001]; SAP Barcelona 4 febrero 2014 [CENDOJ 08019370182014100104].

${ }^{30}$ SAP Baleares 9 febrero 2018 [ECLI:ES:APIB:2018:267].
} 
entrar en él y de fijar su residencia en el lugar que elija de conformidad con lo establecido en el art. 19 de la Constitución Española ${ }^{31}$.

Las libertades de circulación y de residencia se encuentran reguladas en la Sección $1^{\text {a }}$ del Capítulo II del Título I de la Constitución y gozan de la máxima protección que nuestra Carta Magna otorga a los derechos y libertades fundamentales. Se trata de materias sometidas a reserva de ley orgánica (art. 81 de la Constitución Española), que en todo caso deberá respetar su contenido esencial y vinculan a todos los poderes públicos (art. 53.1 de la Constitución Española).

40. La libertad de movimiento de las personas físicas, padres e hijos menores de edad, -en su consideración como derecho de la persona-, no viene determinada únicamente por el ordenamiento interno español sino también por el Derecho de la Unión europea. De esa manera, puede afirmarse, con F. SALERNo, que la libertad de circulación adquiere una dimensión supranacional ${ }^{32}$. Así, el derecho a la libre circulación de las personas se recoge en el art. 18 del Tratado Constitutivo de la Unión Europea ${ }^{33}$, así como también en el art. 45 de la Carta de los Derechos Fundamentales de la Unión Europea ${ }^{34}$. La Directiva 2004/38/CE del Parlamento Europeo y del Consejo, de 29 de abril de 2004, relativa al derecho de los ciudadanos de la Unión y de los miembros de sus familias ${ }^{35}$, pretende alentar a los ciudadanos de la Unión Europea a ejercer su derecho a la libre circulación y residencia en los Estados miembros ${ }^{36}$. Por otra parte, la libertad de circulación y residencia ha de ser relacionada con lo establecido en el art. 139.2 de la Constitución española, de manera que ninguna autoridad podrá adoptar medidas que directa o indirectamente obstaculicen la libertad de circulación y establecimiento de personas en todo el territorio español.

41. Pues bien, en este momento la pregunta surge espontánea: ¿puede el interés del menor incidir en el efectivo desarrollo de estos derechos de la persona? Tanto en los supuestos de autorización de domicilio de uno de los progenitores con un hijo menor de edad, como en los casos de denegación de traslado de domicilio, pueden quedar afectados los derechos de los progenitores, y más concretamente al derecho a la libertad de movimiento de la persona y el derecho a establecer libremente su residencia así como el de su familia.

${ }^{31}$ Art. 19 Constitución española: "los españoles tienen derecho a elegir libremente su residencia y a circular por el territorio nacional. Asimismo, tienen derecho a entrar y salir libremente de España en los términos que la ley establezca. Este derecho no podrá ser limitado por motivos políticos o ideológicos".

${ }^{32}$ F. SALERNo, "I diritti fondamentali della persona straniera nel diritto internazionale privato: un proposta metodologica", RDIPP, 2014, pp. 773-802. También, en el mismo sentido, R. BARATTA, "Derechos fundamentales y Derecho internacional privado de familia", AEDIP, t. XVI, 2016, pp. 103-126.

${ }^{33}$ Art. 21 (antiguo artículo 18 TCE) TFUE: "1. Todo ciudadano de la Unión tendrá derecho a circular y residir libremente en el territorio de los Estados miembros, con sujeción a las limitaciones y condiciones previstas en los Tratados y en las disposiciones adoptadas para su aplicación. | 2. Cuando una acción de la Unión resulte necesaria para alcanzar este objetivo, y a menos que los Tratados hayan previsto los poderes de acción al respecto, el Parlamento Europeo y el Consejo podrán adoptar, con arreglo al procedimiento legislativo ordinario disposiciones destinadas a facilitar el ejercicio de los derechos contemplados en el apartado 1.|3. A los efectos contemplados en el apartado 1, y salvo que los Tratados establezcan poderes de actuación para ello, el Consejo podrá adoptar, con arreglo a un procedimiento legislativo especial, medidas sobre seguridad social o protección social. El Consejo se pronunciará por unanimidad previa consulta al Parlamento Europeo".

${ }^{34}$ Art. 45 de la Carta de los Derechos Fundamentales de la Unión Europea: "Todo ciudadano de la Unión tiene derecho a circular y residir libremente en el territorio de los Estados miembros. 2. De conformidad con lo dispuesto en el Tratado constitutivo de la Comunidad Europea, se podrá conceder libertad de circulación y de residencia a los nacionales de terceros países que residan legalmente en el territorio de un Estado miembro."

${ }^{35}$ Directiva 2004/38/CE del Parlamento Europeo y del Consejo, de 29 de abril de 2004, relativa al derecho de los ciudadanos de la Unión y de los miembros de sus familias a circular y residir libremente en el territorio de los Estados miembros por la que se modifica el Reglamento (CEE) n 1612/68 y se derogan las Directivas 64/221/CEE, 68/360/CEE, 72/194/CEE, 73/148/CEE, 75/34/CEE, 75/35/CEE, 90/364/CEE, 90/365/CEE y 93/96/CEE (Texto pertinente a efectos del EEE) (DOUE L 158 de 30 abril 2004.

${ }^{36}$ En virtud de la Directiva 2004/38/CE, se consideran miembros de la familia a: el cónyuge (también cuando es del mismo sexo, tal como precisó el Tribunal de Justicia de la Unión Europea en su STJUE 5 junio 2018, C-673/16, Coman-Hamilton [ECLI:EU:C:2018:385]), la pareja registrada, si la legislación del Estado miembro de acogida equipara la relación de pareja registrada al matrimonio; los descendientes directos menores de veintiún años o a cargo, incluidos los del cónyuge o de la pareja registrada; y los ascendientes directos a cargo, incluidos los del cónyuge o de la pareja registrada 
42. Como ha indicado la doctrina del Tribunal Constitucional, la restricción de los derechos fundamentales puede operar, -y por tanto es constitucionalmente legítima-, cuando cumple con el principio de proporcionalidad:

"(...) la estricta observancia del principio de proporcionalidad, concretado, a su vez, en las tres siguientes condiciones: «si tal medida es susceptible de conseguir el objetivo propuesto (juicio de idoneidad); si, además, es necesaria, en el sentido de que no exista otra medida más moderada para la consecución de tal propósito con igual eficacia (juicio de necesidad); y, finalmente, si la misma es ponderada o equilibrada, por derivarse de ella más beneficios o ventajas para el interés general que perjuicios sobre otros bienes o valores en conflicto (juicio de proporcionalidad en sentido estricto)" (STC 199/2013, de 5 de diciembre, $F J 7)^{37}$.

43. El auto dictado por la Audiencia Provincial de Barcelona de 9 de octubre de 2019 y aquí comentado se hace eco de la doctrina del Tribunal Constitucional, -aunque no la menciona expresamente-, que ha subrayado que las resoluciones judiciales españolas en las que se acuerda el cambio de domicilio de los menores de edad, han de respetar el principio de "proporcionalidad constitucional". En este contexto constitucional, la medida judicial acordada observará el principio de proporcionalidad si la autorización de traslado, o su denegación, (i) es idónea para proteger el interés del menor (juicio de idoneidad); (ii) si la medida judicial es necesaria, y no existe posibilidad de acordar cualquier otra medida más moderada para conseguir el objetivo pretendido (juicio de necesidad); $\mathrm{y}$, finalmente, (iii) si la medida judicial sobre el traslado es equilibrada por ser las más beneficiosa y menos perjudicial para todos los derechos en juego (juicio de proporcionalidad en sentido estricto).

44. Por tanto, cuando el progenitor cuidador principal, a quien se ha atribuido la guarda y custodia del hijo menor por resolución judicial, expresa su deseo de trasladar su domicilio está ejerciendo su derecho a la libre circulación. Ahora bien, si pretende trasladar también el domicilio del hijo menor, y puesto que dicha decisión no corresponde de forma unilateral al progenitor custodio, habrá de ser valorado su derecho fundamental de residencia, domicilio y deambulación en relación con el interés del menor, que debe ser tutelado de manera preferente. Y al realizar ese juicio de valor, el TS se ha pronunciado en el sentido de adoptar decisiones que tiendan a obtener el mayor beneficio para el menor en caso de traslado de su domicilio, de tal manera que en caso de incidir en el derecho del progenitor en su libertad de movimiento, prevalecerá el interés del menor incluso si ello pudiera comportar un cambio en el régimen de guarda y custodia acordado previamente mediante en sentencia judicial. Así, la sentencia del Tribunal Supremo ${ }^{0}$ 642/2012 de 26 de octubre de $2012^{38}$ precisa:

"Es cierto que la Constitución Española en su artículo 19 determina el derecho de los españoles a elegir libremente su residencia, y a salir de España en los términos que la ley establezca. Pero el problema no es este. El problema se suscita sobre la procedencia o improcedencia de pasar la menor a residir en otro lugar, lo que puede comportar un cambio radical tanto de su entorno social como parental, con problemas de adaptación. De afectar el cambio de residencia a los intereses de la menor, que deben de ser preferentemente tutelados, podría conllevar, un cambio de la guarda y custodia".

45. Siguen el mismo criterio que la anterior las sentencias del Tribunal Supremo de 20 octubre 2014 y de 18 enero $2017^{39}$.

46. En consecuencia, respecto a los cambios de domicilio del menor y su relación con la patria potestad y con el ejercicio del derecho a la circulación de quien solicita trasladar su domicilio, el TS viene sosteniendo lo siguiente.

\footnotetext{
${ }^{37}$ Véase STC 199/2003, de 5 de diciembre (SP/SENT/743798), FJ7 y STC 23/2014, de 13 de febrero (SP/SENT/753483).

${ }^{38}$ STS 26 octubre 2012, no 642/2012 [CENDOJ: 28079110012012100608].

${ }^{39}$ STS 20 octubre 2014, $\mathrm{n}^{\mathrm{o}}$ 536/2014 [CENDOJ: 28079110012014100504]; STS 18 enero 2017, $\mathrm{n}^{\mathrm{o}}$ 18/2017 [CENDOJ: $28079110012017100002]$.
} 
$1^{\circ}$ ) La decisión sobre el lugar de la residencia habitual del menor y su eventual cambio está incluida en la patria potestad, cuya titularidad, con carácter general, es conjunta de ambos progenitores. Por tanto, el cambio de domicilio del menor ha de ser acordado de mutuo acuerdo por ambos padres y no puede ser decidido de forma unilateral por uno solo de los progenitores.

$2^{\circ}$ ) El ejercicio del derecho fundamental a la libertad de circulación del progenitor que pretende trasladar su domicilio con el menor puede conllevar un cambio de la titularidad de la guarda y custodia acordada previamente mediante resolución judicial. Y ello porque la protección del menor será preferente, con independencia de que el efectivo ejercicio del citado derecho fundamental se vea colisionado con ello.

\section{El interés del menor y el cambio del domicilio del menor. Criterios para su determinación y valoración judicial}

\section{A) Casos internos. La jurisprudencia toma el poder. EI Tribunal Supremo, maker of rules}

47. Es jurisprudencia consolidada del Tribunal Supremo español que el principio rector de toda decisión judicial relativa a los menores debeajustarse al principio del interés superior del menor ${ }^{40}$. Es también un mandato derivado de innumerables instrumentos legales españoles, europeos e internacionales, lo que ha hecho que, con toda Justicia, se pueda afirmar que el Derecho de Familia español es, en la actualidad, un "Derecho puerocéntrico", en feliz expresión de E. JAYME ${ }^{41}$. Se trata del interés preferentemente tutelado por la ley española y prevalece frente a cualquier otro interés que se pueda tomar en consideración para adoptar una medida relativa a los menores. Y ese interés, en el caso que nos ocupa, se concreta en que si se autoriza el traslado del menor no quede afectado desarrollo emocional del menor, la progresión de su personalidad, su estabilidad y el contacto con progenitores y hermanos ${ }^{42}$.

48. El juez español, cuando deba decidir si lo mejor para el menor es quedarse en la misma ciudad o trasladarse a otra distinta, habrá de hacer una simulación de escenarios basada en hechos objetivos y deberá plantearse cómo se va a solucionar en la nueva ciudad el problema de la vivienda, colegio, atención médica, apoyos del progenitor custodio, etc.. Y esos mismos elementos tendrá que valorarlos el juzgador en la ciudad donde actualmente reside.

49. En un marco supranacional, la Convención de los Derechos del Niño de la Asamblea General de las Naciones Unidas ${ }^{43}$, de 20 de noviembre de 1989, ratificada por España en 1990, señala que se atenderá primordialmente al interés del menor en todas las medidas concernientes a los niños que tomen las autoridades públicas y los tribunales (art. 3). Son diferentes los preceptos de la Convención que hacen referencia, por un lado, al derecho del niño a relacionarse con ambos padres (art. 10.2), por otro, a la obligación común que tienen ambos progenitores de respecto a la crianza y desarrollo del niño (art. 18)

50. La normativa internacional tiene su reflejo en la legislación española, concretamente en la Ley Orgánica 1/1996, de 15 de enero, de Protección Jurídica del Menor, modificada por la LO 8/201544.

\footnotetext{
40 STS de 19 de noviembre de 2015, nº 664/2015, Recurso de casación n 2724/2014, ponente Francisco Javier Arroyo

${ }^{41}$ E. JAYME, "Identité culturelle et intégration: le droit international privé postmoderne", RCADI, 1995, vol.251, pp. 9-267; ID., "Kulturelle Identität und Kindeswohl im internationalen Kindschaftsrecht", IPRax, 1996, 4, pp. 237 y ss.; ID., "Diritto di famiglia: società multiculturale e nuovi sviluppi del diritto internazionale privato", RDIPP, 1993, pp. 295-304.

42 TS 748/2014, de 11 de diciembre; STS 642/2012.

${ }^{43}$ Instrumento de ratificación de la Convención de los Derechos del Niño de la Asamblea General de las Naciones Unidas, de 20 de noviembre de 1989 (BOE núm. 313 de 31 diciembre 1990).

${ }^{44}$ Ley Orgánica 1/1996, de 15 de enero, de Protección Jurídica del Menor, de modificación parcial del Código Civil y de la Ley de Enjuiciamiento Civil (BOE núm. 15, de 17 enero 1996).
} Fiestas 
El art. 2 de la indicada ley determina que los aspectos en los que se especifica el interés del menor son la satisfacción de las necesidades básicas, tanto materiales, físicas y educativas como emocionales y afectivas; el mantenimiento de su entorno familiar; y la preservación de la identidad, cultura, religión, convicciones, orientación e identidad sexual o idioma del menor.

51. El auto de la Audiencia Provincial de Barcelona que se analiza en este trabajo, con cita de resoluciones dictadas por el Tribunal de Justicia de Cataluña y de la Audiencia Provincial de Barcelona, realiza una exhaustiva enumeración de los criterios a considerar para autorizar o no un cambio de domicilio ${ }^{45}$. En esta línea, señala el juzgador que:

"hay que ponderar los diferentes intereses en juego - los del niño, los de los padres y los de orden público- $y$, en concreto, la vinculación con la figura parental que quiere el cambio, la motivación legítima de tal progenitor o progenitora, la falta de implicación del otro, la edad del menor, la capacidad de adaptación del menor, la familiariedad del menor con el lugar de traslado, la garantía de mayor bienestar para el menor derivada del bienestar de su cuidador, la posibilidad del mantenimiento de un régimen de relación suficiente con el progenitor que se queda, la opinión del niño teniendo en cuenta su edad y madurez, las propuestas respecto a los arreglos prácticos de la reubicación (alojamiento, educación y empleo), los motivos a favor o en contra de la reubicación cuando sea importante para la determinación del resultado, cualquier antecedente de violencia o abuso familiar, el impacto que producirá la concesión o denegación de la reubicación del niño, en el contexto de su familia, etc.."

52. A partir de los mencionados criterios, fundamento esencial de su decisión, el auto de la Audiencia Provincial de Barcelona de 9 de octubre de 2019 señala que la decisión de la madre fue precipitada. Ésta realizó el cambio de domicilio de su hijo menor de una manera unilateral y sin el debido consentimiento paterno, así como desprovista de toda autorización judicial. Se trató, pues, de un traslado de domicilio del menor efectuado por la vía de hecho, sin atención al derecho del menor a relacionarse con sus padres, y sin respeto por la función judicial en estos casos de desacuerdos entre los progenitores.

Como ha indicado M. Herranz Ballesteros, la cuestión del cambio del domicilio del menor ha llegado a los estrados del Tribunal Supremo a través del recurso de casación, vista la presencia de "interés casacional" (art. 477.3 LEC) ${ }^{46}$. La diferente e incluso contradictoria jurisprudencia de las Audiencias Provinciales al respecto y la desviación de ciertas Audiencias Provinciales de la doctrina del Tribunal Supremo sobre el particular, constituyen los dos elementos que han permitido a éste forjar una consolidada doctrina sobre el régimen jurídico del cambio de domicilio del menor, tanto en los casos en los que éste se produce dentro de España como cuando se verifica desde un país a otro.

53. En la línea del razonamiento empleado por el auto de la Audiencia Provincial de Barcelona de referencia, la jurisprudencia del Tribunal Supremo toma en consideración diversos criterios para valorar adecuadamente la procedencia de un cambio de domicilio del menor. Entre tales criterios, elementos y datos, se deben subrayar, como más relevantes, los siguientes ${ }^{47}$.

a) Razonabilidad del cambio. Es decir, que el traslado de domicilio del menor no obedezca a un mero capricho del progenitor, sin justificación alguna, o que el traslado esté guiado por

${ }^{45}$ STSJ Cataluña de 14 julio 2016 [ROJ: STSJ CAT 6060/2016 - ECLI:ESTSJCAT:2016:6061); STSJ 21 diciembre 2015 [ROJ: STSJ CAT12437/2015 - ECLI:ESTSJCAT:2015:12437]; SAP Barcelona 17 enero 2018 [ROJ: 155/2018]; STSJ Cataluña 21 diciembre 2015 [ROJ: STSJ CAT12437/2015 - ECLI:ESTSJCAT:2015:12437].

46 Vid. M. Herranz Ballesteros, "Traslado del domicilio del menor en la jurisprudencia del Tribunal Supremo", en A.-L. Calvo Caravaca/J. Carrascosa González (Dir.), El Tribunal Supremo y el Derecho Internacional Privado, vol. 2, Murcia, Rapid Centro Color S.L., 2019, pp. 567-586.

${ }^{47}$ STS 17 octubre 2018 [ROJ: STS 3527/2018 - ECLI: TS:2018:3527]; STS 18 abril 2018 [ROJ: STS 1383/2018 - ECLI: TS:2018:1383]; STS 12 enero 2017 [ROJ: STS 18/2017 - ECLI: TS:2017:18]; STS 10 septiembre 2015 [ROJ: STS 3796/201 - ECLI: TS:2015:3796]. Vid. A.J. Pérez MarTín, "Peticiones de cambio de custodia por traslado del progenitor custodio a la ciudad donde reside su nueva pareja”, Revista de Derecho de Familia, no 83, Abril-Junio 2019. 
el ánimo de restringir o eliminar la relación de los hijos con el otro progenitor, de manera que se busque con ello el propósito malintencionado e irracional de entorpecer las relaciones parentales con el progenitor no custodio ${ }^{48}$.

b) Fecha en la que se ha producido el cambio de residencia. Si se tiene en consideración que un número importante de traslados del menor se realiza siguiendo la estela de los hechos consumados, esto es, "a las bravas", no es difícil llegar a la conclusión de que, finalmente, y ante la consolidación de la residencia del menor en otra ciudad o en otro país, el Tribunal Supremo haya valorado el interés del menor en función del tiempo de permanencia en su nueva residencia ${ }^{49}$.

c) Vinculación afectiva y proximidad de los hijos con ambos progenitores. Criterio que supone que prime de manera especial para valorar el interés del menor quién es el cuidador principal y si apartarle de éste último puede perjudicar las dinámicas educativas y de organización vital de los hijos ${ }^{50}$.

d) La opinión del menor sobre el cambio de residencia. Dicha opinión tendrá una especial relevancia en función de la edad que tenga dicho menor, ya que éste será más receptivo a un traslado en edades tempranas, mientras que en la adolescencia podría mostrar mayor reticencia al cambio de domicilio ${ }^{51}$.

\section{B) Casos internacionales. La regla material corrige a la regla conflictual a través del interés del menor.}

54. En el ámbito del Derecho internacional privado, los cambios de domicilio del menor de un país a otro pueden estar sujetos a lo que disponga un Derecho extranjero. En efecto, el Derecho del país de la residencia habitual del menor rige esta cuestión (arts. 15-17 Convenio de La Haya 19 octubre 1996). En estos casos, se verifica el temido y misterioso "salto en la oscuridad" (Sprung ins Dunkle), propio de toda norma de conflicto clásica, en famosa expresión debida a L. RAAPE ${ }^{52}$. Habrá, pues, que habrá que estar a lo que establezca tal Derecho extranjero al respecto. Los preceptos citado pueden remitir la regulación de la cuestión a un Derecho extranjero del que, en principio se desconocen sus normas legales y los resultados a los que conduce la aplicación de las mismas. Y sabido es, como muestra el estudio de L. LóPEZ-Muelas / P. ZABALGO, que los diferentes Derechos estatales atribuyen la custodia del menor, en casos de divorcio y similares, con arreglo a criterios muy distintos ${ }^{53}$. La preferencia en favor de la madre, ilustra N. Lowe, sigue siendo un parámetro muy extendido en numerosas legislaciones ${ }^{54}$.

${ }^{48}$ STS 23 julio 2018, $n^{\circ}$ 482/2018 [CENDOJ: 28079110012018100458]. por la que se atribuye la custodia al padre ya que " 1 . No ha existido una razón objetiva que justifique el cambio de criterio de la madre respecto al traslado de la residencia; $2^{\circ}$. Por el contrario, dicha decisión aparece como resultado de su postura poco favorecedora del contacto entre padre e hijo o, al menos, como manifestación de la poca importancia atribuida a tal relación; $3^{\circ}$. No existe prueba alguna de que el cambio favorezca al menor. Antes bien, por efecto del traslado se habría de producir una situación forzada de desubicación que podría haberse evitado con la permanencia de la madre en la ciudad de Melilla".

${ }^{49}$ STS 18 abril 2018 [ECLI:ES:TS:2018:1414], en la que autoriza el cambio de domicilio de un menor a Oñati efectuada tres años antes, por lo que no considera aconsejable trasladar de nuevo al niño ya adaptado a Oñati.

${ }^{50}$ SAP Barcelona 1 abril 2016 [ECLI: ES:APB:2016:3423], que favorece el cambio de domicilio de la madre y sus hijos ya que es la que ha asumido las principales cargas parentales y no puede se le puede exigir a dicha progenitora que renuncie a sus expectativas vitales y a su felicidad personal formando una nueva familia por la sola causa de garantizar la servidumbre de las visitas del padre a los hijos.

${ }^{51}$ SAP Barcelona 8 abril 2016 [ECLI: ES:APB:2016:3303 ]en la que se analiza las reticencias al cambio de domicilio extraídas de la exploración de los menores.

${ }^{52}$ L. RAAPE, "Les rapports juridiques entre parents et enfants comme point de départ d'une explication pratique d'anciens et de nouveaux problemes du droit international privé”, RCADI, 1934, vol.50, pp. 405-544.

${ }^{53}$ L. LóPEZ-Muelas / P. ZABALGo, "La regulación de la patria potestad y guarda y custodia en derecho comparado: España, Italia, Inglaterra, Alemania, Chile y EE.UU”, Diario La Ley No 9443, Sección Tribuna, 25 de Junio de 2019.

${ }^{54} \mathrm{~N}$. Lowe, "Une étude sur les droits et le statut juridique des enfants qui sont élevés dans différentes formes maritales et non maritales de partenariat et de cohabitation", Consejo de Europa, Estrasburgo, 25 de septiembre de 2009, CJ-FA (2008) 5, pp. 30-32. 
Es en este punto donde se aprecia una posible y compleja discordancia entre culturas, valores y normas jurídicas, afirma M.V. CARAUSAN ${ }^{55}$.

Pues bien, nada que temer, porque ese "paracaídas del Derecho internacional privado", como señaló P. Mengozzi, que es el orden público internacional, está siempre vigilante ${ }^{56}$. El principio del interés del menor constituye la columna vertebral esencial del orden público internacional español y opera como correctivo en los casos en los que un Derecho extranjero permita un cambio de domicilio del menor que perjudique a éste en cualquier modo. Como ha escrito S. VRELLIS, en realidad el interés del menor es un valor, un valor vigente en Derecho Europeo y en Derecho nacional, en Derecho español, de modo que la solución jurídica que pueda considerarse mejor es la que encaja de modo más satisfactorio con dicho valor ${ }^{57}$. La regla conflictual es la primera, sí, pero la corrección material que transporta el orden público internacional garantiza, en todo caso, y como hace notar R.M. MourA RAMOS, una prevalencia del interés del menor en estos supuestos ${ }^{58}$.

55. Es preciso añadir que, en los casos con elementos internacionales, para decidir si el titular de la responsabilidad parental puede trasladar a otro país su domicilio y también el domicilio del menor cuya custodia ostenta, los tribunales españoles emplean cada vez con mayor frecuencia los parámetros recogidos por la Conferencia de La Haya de Derecho internacional privado como resultado de una reunión entre expertos de varios Estados celebrada en Washington en marzo de 2010.

Se trata de una serie de elementos, datos y criterios materiales que resultan ser similares a los que viene utilizando el Tribunal Supremo español en los cambios de domicilio de los menores de edad: el derecho del niño a mantener relacionales personales con ambos progenitores; la opinión del menor; las razones del traslado; la existencia de un clima familiar violento; las relaciones familiares previas; las decisiones familiares previas en materia de custodia y derechos de visita; el impacto de una negativa al traslado sobre el niño y los padres; la naturaleza de las relaciones paterno-filiales y el compromiso del progenitor que quiere trasladarse respecto al mantenimiento de las relaciones personales con el otro progenitor; si las propuestas para el ejercicio del derecho de visita son realistas, entre otras.

56. En un intento más que loable de unificar criterios internacionales con los propios del Derecho interno español para tomar una decisión respecto al traslado del menor con su madre, resulta curioso percibir que la resolución que se examina en el presente trabajo, -este auto de la Audiencia Provincial de Barcelona de 9 de octubre de 2019-, hace referencia en sus fundamentos de Derecho a los criterios establecidos por la Comisión Europea de Derecho de familia (UE) en los Principios de Derecho Europeo de Familia relativos a la responsabilidad parental, en cuyo capítulo V titulado "Contenido de la responsabilidad parental", recoge en su principio 3:21, lo que sigue: "Cambio de residencia" que indica que "(3) La autoridad competente tendrá especialmente en cuenta: (a) la edad y la opinión del niño; (b) el derecho del niño a mantener relaciones personales con los otros titulares de la responsabilidad parental; (c) la capacidad y voluntad de los titulares de la responsabilidad parental para cooperar; (d) la situación personal de los titulares de la responsabilidad parental; (e) la distancia geográfica y las facilidades de acceso; (f) la libre circulación de personas".

${ }^{55}$ M.V. CARAUSAN, "Is European Union at the Heart of Citizens' Identity?", Juridica, 2011, p. 59, available at SSRN: https:// ssrn.com/abstract $=1987158 . \mathrm{v}$

56 P. Mengozzi, Il diritto internazionale privato italiano, Ed. Scientifica, Napoli, 2004, pp. 200-204.

${ }^{57}$ S. VReLLIS, "Conflit ou coordination de valeurs en droit international privé. A la recherche de la justice", RCADI, 2007 , vol. 328, pp. 175-486.

${ }^{58}$ R.M. Moura Ramos, "Regards sur les sources et les méthodes du droit international privé de la famille dans l'espace européen”, en I. Pretelli/G.P. Romano/T. Rossi (ÉDs.), Tui Memores - La dimensión culturelle du droit international privé. Actes de la Journée en l'honneur de Tito Ballarino du 13 juin 2014 à Lausanne et Essais recueillis par ses amis et élèves, Publications de l'Institut suisse de droit comparé, Genève, Zurich, Schulthess Éditions Romandes, 2017, pp. 85-131. Muy similar la idea, también, en D. MARTinY, "Overriding mandatory provisions in EU family law regulations", en International and national perspectives on child and family law: essays in honour of Nigel Lowe, Cambridge, Intersentia, 2018, pp. 297-311. 
57. Desde una perspectiva de un mundo globalizado como el actual, y para tratar de contestar a la difícil pregunta de qué es el interés del menor, esto es, con quién estará mejor el niño, con su padre o con su madre, se debe huir de posturas de inmovilismo y de criterios personales. En esta línea, la sentencia de la Audiencia Provincial de Tarragona, Sección 1a , de 27 de abril de 2017 entiende que no cabe partir de "un criterio inmovilista de la familia que se enfrenta con el modo de vida actual en que los cambios de residencia y los matrimonios entre nacionales de diferentes países es habitual"s9.

58. En íntima relación con esta línea doctrinal, es importante tener en consideración que los menores que son fruto de progenitores de diferentes nacionalidades o que han crecido en un país diferente al de su nacionalidad, suelen ser acreedores de dos o más culturas y pueden tener entornos familiares en países distintos a los que se desplazan con relativa frecuencia. Por ello, estos menores pueden tener su arraigo en dos países distintos y su identidad puede ser, y de hecho es, multicultural, mutilingüe y multinacional. En este sentido, no se puede dar preferencia a un entorno familiar o cultural sobre otro. Lo esencial será determinar si el cambio de domicilio redundará en el beneficio del menor, más allá de criterios de nacionalidad, lugar de nacimiento o procedencia de los progenitores.

59. Como indica la Sentencia el Tribunal Supremo de 10 septiembre 2015, no todos los cambios son necesariamente negativos. Como norma general los menores deben permanecer con el progenitor que tenga mejor posición para atenderlos, y su valoración requiere analizar cada aspecto de la vida del menor, de cada concreto menor. Importante tarea será, por tanto, con el fin de acreditar el interés del menor, desplegar una actividad probatoria prolija y completa de todas las circunstancias del menor y de su entorno social, familiar y emocional.

\section{Perspectiva procedimental para la autorización / desautorización judicial del cambio de domi- cilio del menor}

60. En Derecho español, los cambios de domicilio del menor habrán de ser autorizados judicialmente de no existir el mutuo acuerdo de los progenitores pero el Código Civil no señala el procedimiento en que deben decidirse las discrepancias en el ejercicio de la patria potestad. El art. 158 CC determina que la decisión judicial del traslado se adoptará dentro de cualquier proceso penal, civil o de jurisdicción voluntaria. El CCCat dispone en su art.236-11 que en caso de desacuerdo en el ejercicio de la potestad, cualquiera de los progenitores puede acudir a la autoridad judicial habiendo escuchado al otro progenitor o a los hijos mayores de doce años o menores que tengan conocimiento.

61. Por tanto, dos opciones procedimentales parecen claras en Derecho interno para solicitar un cambio en la residencia habitual de los hijos menores: el procedimiento para modificación de medidas previsto en el art. 775 LEC y el expediente de jurisdicción voluntaria que regula las discrepancias en el ejercicio de la patria potestad de los arts. 85 y 86 de la Ley 15/2015, relativos a la intervención judicial en caso de discrepancias en el ejercicio de la patria potestad ${ }^{60}$.

\footnotetext{
$59 \mathrm{SP} / \mathrm{SENT} / 1012572$.

${ }^{60}$ Ley 15/2015, de 2 de julio, de la Jurisdicción Voluntaria (BOE núm. 158 de 3 julio 2015). Art. 85 LJV: "1. En los expedientes a que se refiere este Capítulo, una vez admitida la solicitud por el Secretario judicial, éste citará a la comparecencia al solicitante, al Ministerio Fiscal, a los progenitores, guardadores o tutores cuando proceda, a la persona con capacidad modificada judicialmente, en su caso o al menor si tuviere suficiente madurez y, en todo caso, si fuere mayor de 12 años. Si el titular de la patria potestad fuese un menor no emancipado, se citará también a sus progenitores y, a falta de éstos, a su tutor. Se podrá también acordar la citación de otros interesados.2. El Juez podrá acordar, de oficio o a instancia del solicitante, de los demás interesados o del Ministerio Fiscal, la práctica durante la comparecencia de las diligencias que considere oportunas. Si estas actuaciones tuvieran lugar después de la comparecencia, se dará traslado del acta correspondiente a los interesados para que puedan efectuar alegaciones en el plazo de cinco días.3. No será preceptiva la intervención de Abogado ni de Procurador para promover y actuar en estos expedientes.” Art. 86: “. Se aplicarán las disposiciones de esta sección cuando el Juez deba intervenir en los casos de desacuerdo en el ejercicio de la patria potestad ejercitada conjuntamente por los progenitores. También serán de aplicación en los casos en que esté legalmente prevista la autorización o intervención judicial cuando el titular de
} 
Es competente para el conocimiento de los asuntos relativos a autorizaciones judiciales relativas al ejercicio de la patria potestad el Juzgado de Primera Instancia del domicilio o, en su defecto, de la residencia del hijo. Aunque, si el ejercicio conjunto de la patria potestad por los progenitores hubiera sido establecido por resolución judicial, esto es, si existiera una resolución judicial previa que regule las medidas derivadas de la ruptura, tal y como es el caso objeto de este estudio, resulta competente para conocer del expediente de jurisdicción voluntaria el Juzgado de Primera Instancia que hubiera acordado previamente las medidas paterno-filiares (art. 86.2 de la Ley 15/2015).

62. El procedimiento de jurisdicción voluntaria para autorizar judicialmente los cambios de domicilio del menor se puede iniciar por solicitud de cualquiera de las personas que son titulares de la patria potestad (art. 86.3 de la Ley 15/2015). Una vez admitida la solicitud por el Secretario judicial, continuará el procedimiento con la celebración de una comparecencia en la que se citará al solicitante, al Ministerio Fiscal, a los progenitores, guardadores o tutores. Igualmente, se citará al menor si tuviere suficiente madurez y, en todo caso, si fuere mayor de 12 años (art. 85.1 de la Ley 15/2015). Durante la práctica de la comparecencia el Juez puede acordar, de oficio o a instancia de las partes y demás interesados la práctica las diligencias que considere oportunas (art. 85.2 de la Ley 15/2015).

63. El auto de la Audiencia Provincial de Barcelona de 9 de octubre de 2019 pone de relieve en su fundamentación jurídica que el procedimiento seguido por el padre para desautorizar el traslado (arts. 88 y 89 de la Ley 15/2015, de la Jurisdicción Voluntaria) no reúne los requisitos de suficiencia de alegación y prueba. Además, en un procedimiento de jurisdicción voluntaria como el seguido por el padre, podría quedar alterado el principio de intangibilidad de las sentencias ya que previamente existía una sentencia judicial firme sobre distintas medidas paterno-filiares en relación al hijo menor. Por tanto, la discrepancia entre los padres "no es puntual y supone un impacto o influencia importante en las medidas adoptadas en el procedimiento de ruptura". Razones todas ellas que sirven para desautorizar el traslado de domicilio y compeler a los progenitores para que insten un procedimiento de modificación de medidas que resuelva sobre todas las cuestiones a las que afecta el cambio de domicilio del menor (su autorización o no, régimen de visitas del padre, contribución a gastos, etc..)

64. $\mathrm{Y}$ es que, tal y como explica la resolución judicial analizada, en los casos en que existan medidas específicas previas adoptadas por una sentencia judicial, si se produce un cambio de domicilio no consentido por uno de los progenitores y no autorizado judicialmente se deberá acudir (con preferencia a la jurisdicción voluntaria) al procedimiento de modificación de medidas previsto y regulado en el art. 775 LEC $^{61}$ (art. 233-9 CCCat para el caso de Cataluña).

La autorización de cambio de domicilio del menor, cuando existe anteriormente una sentencia firme sobre medidas paterno-filiares, supone necesariamente una pretensión de modificación de efectos de la referida sentencia anterior, puesto que el traslado del hijo "también puede arrastrar un cambio en el sistema de guarda, de centro escolar y actividades de los hijos, en la forma de relacionarse los progenitores con el menor y hasta en el régimen alimenticio y de atención a los gastos de desplazamiento,

la patria potestad fuere un menor de edad no emancipado y hubiere desacuerdo o imposibilidad de sus progenitores o tutor. 2 . Será competente el Juzgado de Primera Instancia del domicilio o, en su defecto, de la residencia del hijo. No obstante, si el ejercicio conjunto de la patria potestad por los progenitores hubiera sido establecido por resolución judicial, será competente para conocer del expediente el Juzgado de Primera Instancia que la hubiera dictado.3. Están legitimados para promover este expediente ambos progenitores, individual o conjuntamente. Si el titular de la patria potestad fuese un menor no emancipado, también estarán legitimados sus progenitores y, a falta de éstos, su tutor".

${ }^{61}$ Art. 775 LEC: "Modificación de las medidas definitivas. 1. El Ministerio Fiscal, habiendo hijos menores o incapacitados y, en todo caso, los cónyuges, podrán solicitar del tribunal que acordó las medidas definitivas, la modificación de las medidas convenidas por los cónyuges o de las adoptadas en defecto de acuerdo, siempre que hayan variado sustancialmente las circunstancias tenidas en cuenta al aprobarlas o acordarlas. | 2. Estas peticiones se tramitarán conforme a lo dispuesto en el artículo 770. No obstante, si la petición se hiciera por ambos cónyuges de común acuerdo o por uno con el consentimiento del otro y acompañando propuesta de convenio regulador, regirá el procedimiento establecido en el artículo 777. | 3. Las partes podrán solicitar, en la demanda o en la contestación, la modificación provisional de las medidas definitivas concedidas en un pleito anterior. Esta petición se sustanciará con arreglo a lo previsto en el artículo 773". 
y por ello tal pretensión no es base con claridad de un procedimiento de intervención judicial por desacuerdo en el ejercicio de la patria potestad ejercida conjuntamente por los progenitores" (Auto de la Audiencia Provincial de Barcelona de 9 de octubre de 2019).

65. Sin embargo, el procedimiento de jurisdicción voluntaria resulta más apropiado cuando no existan medidas previas acordadas por resolución judicial en relación al menor, o se planteen discrepancias concretas respecto a un acto de trascendencia jurídica en la que sea necesario, para que tenga validez, el consenso de ambos progenitores. Es el procedimiento más idóneo cuando la decisión judicial dirimente no altere el equilibrio existente entre el conjunto de las medidas establecidas en sentencia firme ${ }^{62}$.

66. En el caso objeto del auto de la Audiencia Provincial de Barcelona de 9 de octubre de 2019, el juzgador subraya que la discrepancia entre los padres "no es puntual y supone un impacto o influencia importante en las medidas adoptadas en el procedimiento de ruptura". Razones todas ellas que sirven para desautorizar el traslado de domicilio y compeler a los progenitores para que insten un procedimiento de modificación de medidas que resuelva sobre todas las cuestiones a las que afecta el cambio de domicilio del menor (su autorización o no, régimen de visitas del padre, contribución a gastos, etc..), que recoge el art. 775 LEC.

67. Sin embargo, pese a la idoneidad del procedimiento de modificación de medidas para el caso objeto de examen, -cambio de domicilio del menor con sentencia de medidas paterno-filiares previa-, si el padre hubiera instado como primera opción un procedimiento de modificación de medidas, en lugar de un procedimiento de jurisdicción voluntaria, y, finalmente, hubiera obtenido una sentencia que no autorizara el traslado del menor, las consecuencias prácticas de dicha resolución judicial habrían sido lentas y poco seguras en orden a la restitución del menor a su domicilio de origen.

Ello sucede así porque el procedimiento de modificación de medidas regulado en la Ley de Enjuiciamiento Civil, a diferencia de otros instrumentos normativos de Derecho internacional privado que rigen los aspectos civiles de la sustracción internacional de menores, no prevé una "acción directa" para el retorno inmediato del menor a la localidad donde tenía establecida su residencia habitual, máxime cuando la madre, como en el caso aquí objeto de estudio, decidió de forma unilateral y sin consentimiento del otro progenitor y sin acudir, tampoco a la autoridad judicial, cambiar el domicilio del menor por la vía de los hechos consumados. Que es, siempre, recuerda $\mathrm{CH}_{\text {. }}$ CHALAs, la vía más contraria a Derecho, pues es la vía de la fuerza ${ }^{63}$.

68. Es en este punto donde se puede hallar una quiebra, o mejor dicho, un agravio comparativo en el sistema judicial español dependiendo de si el cambio de domicilio del menor sin consentimiento del otro progenitor se ha producido dentro del territorio español o si el mismo ha sido efectuado a otro país distinto a España.

69. En el primero de los casos -traslado no consentido a otra ciudad o población española-, se podrá poner en marcha por el progenitor afectado un procedimiento de modificación de medidas que, a buen seguro, será lento e ineficaz, puesto que no permite actuar con agilidad y rapidez con respecto al traslado ya consumado, así como tampoco prevé una colaboración entre autoridades para la localización y devolución del menor al domicilio de origen. El procedimiento de modificación de medidas de la LEC tampoco dispone de una acción directa dirigida a lograr la restitución del menor al lugar de su residencia habitual anterior.

En el caso resuelto por la Audiencia Provincial de Barcelona que es materia de este análisis, la secuencia de hechos y de procedimientos judiciales instados conduce a una conclusión pesimista en cuanto a la relación entre medios empleados para desautorizar el traslado y resultados. En primer lugar,

\footnotetext{
${ }^{62}$ AAP Barcelona, sec 12, de 31 mayo 2017 [ROJ:AAP B 6367/2017].

${ }^{63} \mathrm{CH}$. Chalas, "Précisions sur la résidence habituelle et la procédure de retour de l'enfant dans le Règlement Bruxelles II bis", RCDIP, 2018-I, pp. 115-125.
} 
porque la madre procedió por la vía de los hechos a consumar un traslado del menor sin consentimiento del otro progenitor. En segundo lugar, porque el procedimiento judicial elegido por el padre para solicitar que el juez desautorizara el cambio de domicilio del niño fue el de jurisdicción voluntaria, que además de tratarse de un procedimiento extremadamente lento en la mayoría de los juzgados españoles, no era el procedimiento idóneo en el caso concreto enjuiciado por existir unas medidas judiciales previas en relación al menor (guarda y custodia, régimen de visitas, alimentos...etc) a las que afectaría la autorización/no autorización del traslado; por lo que el procedimiento judicial idóneo a seguir debía ser el contradictorio de la modificación de medidas. Y en tercer lugar, porque a pesar que la Audiencia Provincial de Barcelona deja sentado en su auto de 9 de octubre de 2019 que la decisión unilateral de la madre fue precipitada y faltó el debido consentimiento paterno, el resultado de un pleito de modificación de medidas resulta totalmente incierto dado el tiempo transcurrido desde el traslado. Y ello porque el cambio de domicilio se llevó a efecto por la madre en el mes de noviembre del año 2018 y, por tanto, cuando se valore el interés del menor en el procedimiento de modificación de medidas, dos o tres años después del traslado, quizá dicho interés haya variado en relación al momento inicial del cambio. No es de extrañar que, cuando se dicte definitiva sentencia, el niño se haya adaptado por completo a su nueva localidad, a sus nuevas circunstancias y no sea conveniente entonces volver a propiciar un cambio de su centro de vida social. Incluso para el caso de que el juez no autorizara el cambio de domicilio del menor, dicha sentencia judicial sería de complicada ejecución por los mismos motivos de adaptación del niño a su nuevo entorno.

70. En el segundo de los casos, esto es, en los supuestos de cambios no consentidos de domicilio a países distintos a España, un traslado brusco y no consentido por el otro progenitor de un menor tendría como respuesta la aplicación inmediata del Convenio de la Haya de 25 de octubre de 1980, siempre que el traslado del menor tenga lugar entre Estados partes en el mismo. Ello, en definitiva, supondría, en primer lugar, una colaboración entre las distintas autoridades de los Estados implicados en orden a la localización y devolución del menor. Y en segundo lugar, la aplicación del convenio referido pondría en funcionamiento la acción directa para garantizar la restitución del menor a territorio español sin cuestionar el fondo del asunto, esto es, quién dispone del derecho a cambiar el domicilio del menor y en qué términos se debe llevar, sen su caso, a efecto.

71. De todo lo anterior se extrae que los instrumentos normativos de Derecho internacional privado que regulan los supuestos transfronterizos de cambio de domicilio del menor garantizan una estructura de cooperación internacional de autoridades para la restitución inmediata del menor de la que adolece el Derecho interno español para situaciones idénticas de cambios de domicilio no consentidos pero consumados dentro de las fronteras de España.

Con la aplicación de normas como el Convenio de La Haya citado se puede lograr el retorno del menor trasladado ilícitamente de un país a otro con pleno respeto del statu quo anterior al traslado, pero sin entrar nunca en el "fondo del asunto". La puesta en marcha de este mecanismo jurídico evita las rupturas bruscas del menor con su medio, esto es, con su centro de vida social y permite velar por el cumplimiento de los derechos de custodia y visita establecidos en el Estado de origen del menor. Con ello, el convenio trata de salvaguardar el derecho del menor a relacionarse con ambos padres ${ }^{64}$. No cabe duda alguna de que ello redundará en el interés del menor, en el fomento de una buena Administración de Justicia y también en una mayor seguridad jurídica. Aplicar estos instrumentos normativos en el ámbito del Derecho interno español, además de llevar consigo las ventajas ya indicadas, daría satisfacción a las exigencias de aplicación uniforme del Derecho de la UE por los Estados. El interés del menor es un valor hoy universal, pero eso significa, precisamente, que cada menor debe disponer de una solución diferente adaptada a su concreta situación como ha sugerido F. JIZENG ${ }^{65}$.

${ }^{64}$ I. LoRente Martínez, Sustracción internacional de menores. Estudio jurisprudencial, práctico y crítico, Madrid, Ed. Dykinson, 2019.

${ }^{65}$ F. JizENG, "The Relative Universality of Human Rights: Theory and Practice", Human Rights, n. 2, March 2013 (https:// ssrn.com/abstract=2593957). 


\section{Reflexiones finales. Europeizar el Derecho español en interés del menor}

72. En un mundo completamente globalizado surgen constantemente nuevas formas de familia. Es el caso de las familias reconstituidas, monoparentales, disgregadas en diversos países, con hijos adoptados y/o nacidos en virtud de técnicas de reproducción asistida o gestación surrogada, formadas por personas del mismo o distinto sexo y tantas otras. El menor se presenta como el centro de gravedad del Derecho de Familia español y europeo, que pasa a ser esencialmente puerocéntrico. El "núcleo común" del Derecho europeo y de los Derechos nacionales de los Estados miembros en este sector es, precisamente, el interés del menor individualmente considerado, puntualiza S. MARINO ${ }^{66}$. En dicho contexto líquido, velozmente cambiante y global, los conflictos entre los titulares de la responsabilidad parental que afectan a la precisión del lugar donde el menor fija su domicilio, son cada vez más frecuentes.

73. La determinación del domicilio del menor no es cuestión baladí. Se trata del núcleo logístico de la vida personal, escolar y emocional del menor. Es el lugar donde éste encuentra la estabilidad vital que necesita para el correcto y libre desarrollo de su personalidad. Por ello, las decisiones jurídicas que afectan a la fijación de dicho domicilio revisten una importancia muy elevada. En los casos de traslado del domicilio del menor dentro del territorio español, el Derecho Civil español, común y autonómico, opera todavía con la tradicional categoría de la "patria potestad". A partir de ahí, se exige un acuerdo entre los titulares de la misma para llevar a cabo ese cambio "nacional" de domicilio y a falta de dicho acuerdo, el juez competente decidirá lo procedente. En ambos casos, el interés del menor opera como parámetro de máxima consideración. Tanto los progenitores como la autoridad judicial deben decidir el lugar del domicilio del menor de modo que ello favorezca la situación personal concreta del menor en cuestión.

74. En los casos de cambio transfronterizo del domicilio del menor dentro del territorio español, el Derecho internacional privado europeo y el Derecho internacional privado español cuentan con armas más eficaces y eficientes. Resulta paradójico que, en un Espacio Europeo de Justicia en el que España está integrada, las reglas jurídicas aplicables sean distintas según se produzca un cambio litigioso del menor dentro de España o dentro de la Unión Europea. Tan Unión Europea es Vigo como París, Alcorcón como Milán.

El menor es siempre el menor y toda norma jurídica que regula el cambio de domicilio, nacional o europeo, debe contar con los mecanismos más adecuados para asegurar la mejor estabilidad vital y desarrollo personal del menor

En este sentido, sería muy conveniente que el Derecho Civil español contase con una acción de retorno directo del menor a su anterior domicilio, similar a la contenida en el Convenio sobre los aspectos civiles de la sustracción internacional de menores, hecho en La Haya el 25 octubre 1980. De ese modo, un menor al que un progenitor ha forzado a cambiar de domicilio desde Murcia a Cáceres, por ejemplo, podría ser restituido directamente a Murcia, de modo que sea el juez de dicha localidad el que decida dónde debe concretarse el domicilio del menor. Así, se evitaría el perverso efecto que produce el art. 86.2 LJV, que permite atribuir la competencia para decidir sobre estos asuntos al "Juzgado de Primera Instancia del domicilio o, en su defecto, de la residencia del hijo". Se trata de impedir que un progenitor sustractor de su hijo "fuerce" la competencia del juez que corresponde al nuevo lugar de situación del menor. Una gran, elevadísimo mérito del citado Convenio sobre los aspectos civiles de la sustracción internacional de menores, hecho en La Haya el 25 octubre 1980 radica en luchar contra las situaciones y actuaciones de "de hecho" que llevan a cabo algunos padres. Impedir que un conflicto jurídico sobre el domicilio del menor se resuelva mediante el recurso a la fuerza debe ser la primera regla de la Justicia en estas controversias. En este sentido, como apunta C. THOMALE, el convenio citado refuerza un "interés del menor anticipado", pues es el juez del lugar el menor se encuentra antes de su traslado el que debe decidir dónde debe tener su domicilio dicho menor ${ }^{67}$.

${ }^{66}$ S. Marino, "Common core or enhanced cooperation in European family law?", en A. Cebrí́n Salvat/I. Lorente MartíNEZ (DIR.), Protección de menores y Derecho Internacional Privado, Granada, Editorial Comares, 2019, pp. 73-90.

${ }^{67}$ C. Thomale, "Das Kinderwohl ex ante - Straßburger zeitgemäße Betrachtungen zur Leihmutterschaft (EGMR, S. 631)", IPRax, 2017-6, pp. 583-590. 
75. Otro punto clave en la regulación del cambio nacional y transfronterizo del domicilio del menor radica en preciar, con mayor claridad, quién tiene el derecho a concretar dicho lugar. A tal efecto, la "responsabilidad parental" aparece como un concepto nuevo, preñado de matices bien dispuestos para determinar las personas que deben decidir sobre el lugar del domicilio del menor. Europeizar el Derecho Civil español a partir de las normas de Derecho internacional privado y sustituir el concepto de patria potestad por el responsabilidad parental es una buena decisión de política jurídica que beneficiaría al menor implicado en un traslado litigioso de su domicilio.

76. Los hijos no son propiedad del Estado ni son tampoco propiedad de los padres. No son propiedad de nadie porque no son ni cosas ni objetos sino sujetos de Derecho, personas titulares de derechos individuales, subjetivos y fundamentales. Ahora bien, para su protección, los menores deben contar con garantías legales que aseguren que los titulares de la responsabilidad parental sobre ellos y también la autoridad judicial, deciden cuál es el lugar de su domicilio, esté dicho lugar situado en España o en otro país, con arreglo a criterios justos que aseguren que tal decisión se toma en el mejor interés del menor. De cada menor en concreto como persona individual. 